\title{
OPEN
}

DOI 10.1515/vtrr-2015-0001

Vocational training: research and realities, Vol. 26, No. 1, 2015

\section{SUCCESS STORIES. A VIEW OF INITIAL VOCATIONAL TRAINING THROUGH THE EYES OF FORMER STUDENTS}

\section{TACCONI Giuseppe}

CARVET (Center for Action Research in Vocational Education and Training), University of Verona, Italy

\begin{abstract}
The paper reports the main results of a research that aimed to explore in depth the role that the experiences within the Salesians' Vocational Training Centers played in influencing the personal and professional profile of former students. To this end, 54 former students from 6 Vocational Training Centers who have recognized as successful in work, personal life and social commitments were participated in the study. The research is not intended to "prove" that training leads to educational success, but to identify the conditions under which the training could promote educational success. Exploring the biographies of some of the lived experiences of former students, I was interested in particular to know what had allowed the trainees - who often come to CFP with heavy burdens, and with great difficulty against a certain type of school - to enhance their potential and succeed as adults, as respected professionals and individuals capable of taking responsibility for themselves and others. Research on training and life stories of former students become therefore also - and above all - a research on the practices of teachers and characteristics of learning environments, from the view of former students. Through the details of the stories collected and analyzed, it is possible to learn the characteristics of environments and educational practices that could assist in finding out the direction for offering best training. The contribution is divided into three parts. In the first, I tried to give a detailed account of how the research comes to take the current shape. The second part deals with the results focusing on the characteristics of the educational environment of the Vocational Training Centers and intervention strategies that the participants have found to be keys to their growth. The third part is the conclusion and offers a discussion of what emerges from the analysis of the data and highlights its major assets.
\end{abstract}

Keywords: Educational practice; Narrative Inquiry; Student; Vocational Education and Training

\section{Background}

This research is created from a collection of testimonies of former students who have completed a course of Initial Vocational Education and Training (IVET) at Salesian* VET Centers (CFP)**, during the period between the sixties and the new millennium, in one of the six Italian regions where the investigation has been conducted. The research focused on the quality of the learning experience in a CFP and its ability in influencing students' biographical path and their personal and professional fulfillment. 
The epistemological assumption of this research is that narratives may be the generative place even of a relevant knowledge on VET. It is an educational research, interested in deepening the understanding of VET practices through testimonies. The account is in fact the more appropriate knowledge model to approach lived experience***. From the analysis of the stories told by students, it is possible to build a theory that can put into words the knowledge generated from the experience (Mortari, 2003, 2010) and to give a rationally justified order to the logics that inspire the training activity. However, this is a humble theory, which does not aspire to generalization, a theory that could be called "extracted" and not "abstract" because it is created by its own stories. While in previous works (Tacconi et al., 2010; Tacconi, 2011) the educational practice has been explored starting from the stories of the teachers, in this research it is explored from the students' point of view (Tacconi et al., 2013)****.

The narration is constitutive of the identity of a person who, as Paul Ricoeur reminds us, is like a "narrative identity" (Ricoeur, 1993, pp. 201-230). It's through the memory and the narration that every one of us comes to life with unique features (Cavarero, 1997). We are not just the sum of our experiences, but what of our past is transformed into experience and has become part of us just through the memory and the narration $\dagger$. If all of this may be said about personal autobiography (Demetrio, 1996), perhaps it can be said also of a discipline as teaching, if we see teaching not as the science that says what teachers have to do but as a field of knowledge that turns his attention to how educational practices actually take place (Damiano, 2006), that gathers stories of practice recognizing in them and between them a sense that reveals its meaning and indicates the possible direction (Tacconi, 2011). This work confronts us with two narrative levels, the personal stories of training of former students and the broader educational research, considered as a collective and collaborative undertaking using stories of training in order to understand more about educational practice. This implies confidence in the narrating and in its ability to reveal deeper aspects of reality (Lackey \& Sosa, 2006).

The objective of this research is to understand the training and working stories of a significant group of former students of initial vocational training programs. This would lead to the exploration of the relationship between the training these people have lived with in the CFP and what they have become today. The hypothesis was that the training experienced in the CFP could have played a significant role in the development of personal biographies. In particular, it was important to understand which were, from the point of view of the students, the quality elements of the training practices used in the CFP that could have been recognized as determinant in directing the students' path. To do so, various stories have been collected (Edmunson, 2002; Coles, 2004), testimonies of who has lived those experiences, in an attempt to delineate the features of an effective model of vocational education and training.

A total of 54 participants have taken part in this research. They are former students of 7 Salesian VET Centres of 6 Italian regions, chosen from among those who had distinguished themselves in work and 
personal life. In April 2010, the Cnos-fapł† contacted the directors of the 60 Italian Salesian CFP asking them to indicate the names and the phone numbers of those former students who were considered as examples of "educational success" in at least two of the following areas: 1) work effort, 2) social and civil commitment (voluntary services, cultural, social or political commitment, etc.) and 3) commitment in Salesian contexts (alumni association, teaching in the CFP, services in the Salesian works). 14 CFP offered their availability. In the following months and throughout 2011, it was possible to contact directly the interested parties arranging interviews in 7 of the 14 CFP available. A total of 54 stories of training have been collected. The research hadn't the objective of involving a representative sample of former students; it was rather interested in the relevance of the testimonies and in their distribution throughout the country. In particular, 31 participants come from the regions of Southern Italy (Sicily: 29 and Puglia: 2), while 23 come from the regions of Northern Italy (Piedmont: 14; Veneto: 5; Emilia Romagna: 3; Lombardy: 1). The subjects indicated for the research are all male. Even if since the 90s, the Salesian VET Centers have also welcomed female students, today there is still a predominance of male students. Concerning the age, only 2 of the participants at the time of the interview were under 29 (they had attended the CFP between the late '90s and early 2000s), and only 2 were older than 60 years (they had then attended the CFP in the mid-60s). 12 participants were between 50 and 59 (they had attended the CFP between 1966 and 1975), 19 were between 40 and 49 (that is, they had been students between 1976 and 1985) and other 19 were between 30 and 39 (they had attended the CFP between 1986 and 1995). Regarding the qualifications, half of the participants have acquired a vocational qualification and then have entered the labour market; the other half after the qualification have continued to study until the end of a five-year course of vocational or technical education ("Maturity exam"); 10 have started college courses and 6 of them have graduated in technical or engineering area. With regard to employment sector, 15 participants currently work as technicians (designers, engine drivers, typographers, analysts), 3 as managers, 18 as entrepreneurs or self-employed; 16 of them are employed as trainers or teachers, mainly in Salesian VET Centers. They all meet the requirements previously indicated as criteria for the selection of participants in this research.

The method chosen to understand the training processes taking place in the VET Centers is the empirical method, related to the narrative Inquiry (Clandinin, 2007). The research technique used for data collection is the narrative interview (Atkinson, 1998). Also the approaches used in the analysis of the collected data, the phenomenological method (Van Manen, 1990; Mortari, 2007) and the grounded theory (Glaser \& Strauss, 1967), have a "narrative" aspect since even in this case the stories of the subjects involved have been extremely important and all the research process has been accompanied by the writing of a research diary (once again a narration). In other words, narrating have characterized all the research: the data collection phase in which the stories have been requested; the analysis phase in which the researchers have 
analysed the narrative units and have used a diary to tell this analysis; the writing phase in which the results and the process of the research have been reported in a narrative form.

Once received the names of the former students who met the criteria described above, it has been proceed to individually contact the participants organizing the data collection phase. On average, the interviews lasted 90 minutes each and took place in the VET Centers or in the workplaces, where a comfortable setting has been arranged in order to allow participants to grasp the sense of the research. The interviews have been carried out in a non-directive way (Rogers, 1997): the interviewer has adopted an attitude of genuine interest, leaving the role of "expert" and becoming a person who asks to know, aware that the other's story is a real gift. The important thing was to keep the attention of the interviewer and the interviewee on the focus of the research that is the lived experience in CFP and the relationship between this experience and future personal and working life. In particular, the interview was about easing the telling of personal situations, anecdotes and episodes, rather than thoughts and considerations of general nature. All the testimonies have been audio recorded and transcribed verbatim.

First of all, data analysis has required a careful reading of all the material by two researchers. After each of the two researchers had read the materials separately, highlighting the units of text based on the object of the research (Mortari, 2007), an initial comparison has been made. In all the texts there were meaningful units, characterized by detailed descriptions of specific situations, as well as thoughts and considerations of the speakers. During the comparison, useful to create a common view between the two coders, we realized that making an analysis in a too analytical way risked to ruin the descriptions of the participants. Therefore the interviews have been transformed into real stories, by removing the questions and connecting a response to another with conjunctions or other words in order to make the story understandable and by replacing the typical expressions of the spoken language with three dots in square brackets $([\ldots])$. During this "cleaning operation" it has been important to be very careful not to alter the meaning of the original text. We realized that even the "text cleaning" became an analysis phase. Once all the interviews had been turned into stories, the meaningful units of the text have been identified and highlighted again. It has been assigned a label to each unit summarizing the content and every label has been categorised in accordance with a thematic affinity. The analysis process has been recursive and has involved several revisions. At last it has been written a report to describe the results of the analysis and the interpretation of data. However, writing, analysis and interpretation of data are interconnected steps so that they are often indiscernible.

\section{Results}

In this part, dedicated to the research findings, for each category it will be reported only a few examples taken from the stories of training; the full results can be read in Tacconi et al., 2013. Throughout the work, 
only the initial of the name of the person interviewed and the identification code of the interview will be written. Also the teachers mentioned in the stories of former students have only their initials written. It has been removed also every reference to the names of the companies. While the name of CFP and the places of origin haven't been changed.

\section{Environment}

The first theme that emerges from the stories of former students is related to the training environment of CFP as a whole. All the descriptions of the centers show a human and serene environment, characterized by high professional and relational quality. One of the common features is the perception that the environment assumed a fundamental role in education. The interviewees give the idea that the VET Center formed an environment where each experience contributed to the personal growth. Here's an example:

There was an atmosphere that surrounded you at every moment: we stayed in class attending the lesson, but as soon as we went out in the yard, Don $\neq$. or one of the other Salesians came near-because they were all in the yard - he followed us in what we were doing and at the same time he gave us some advice, made a joke or suggested some book to read; we were looked after, surrounded by affection, as in a family. Even in the refectory, while we were eating, someone often approached by asking if the food was good or giving some good advice ( $\operatorname{Int} C t 7)$.

The environment is characterised first of all by a friendly atmosphere, by the sharing of the different times of the day, those of commitment and those informal (the courtyard, the refectory) and by intense but regulated social relations. The presence of the Salesians - approaching, expressing concern, offering advices, etc. - seems to be particularly important for the environment, but some interviewees testify that, when they came back to the CFP years later, they found an atmosphere very similar to the one they had left, even if the number of Salesians had changed. It seems that learning takes place by immersion or by contagion, almost "without realizing it", covering various dimensions of personal and social development of individuals. Many former students interviewed talk about educational experiences together with socialization and work experiences, sport and recreational experiences. Purpose of Salesian VET Centers is a well-rounded education. In this regard, the testimony of C. (IntFo1) has a special meaning:

Both work and study were important; for us the study was a step to do, we didn't want to study but we wanted to learn, because we could learn without studying. In the morning, the teachers told us that we should not spend hours and hours on the books; but then P. made us read also books that had nothing to do with the mechanical engineering; P. even made us study psychology, to learn how are the people inside; [...] I've learnt a lot by looking people in the face [...]. While we were here, even if we did not want to study, we learnt. When we came out of here in the evening, we had actually learnt. It has been a complete life experience. Even at that time there were those who did not want to study, but they entered into a certain atmosphere that made 
them learn [...]. Maybe the secret is this: here you did, you worked, you played etc., and so you had the opportunity to learn, especially a way of life: schedules, punctuality, the pride of doing a good work (IntFo1).

You learn by doing, working, playing. Everything contributes to learning. And this method is suitable also for those who believed not to be able to learn. All interviewees describe the environment of the CFP using the words "home" or "family". Within a protective environment in characterized by the sharing of beliefs and values meaningful connections are built, long-lasting genuine relationships marked by affection, able to heal those wounds that, sooner or later, personal history inflicts.

\section{Training}

In the stories of the participants in this research the training experience lived in the VET Centers has unique characteristics that are difficult to find in other contexts. Its peculiarity derives from the fact that VET here is never disconnected from a full and complete personal education of the subjects.

\section{A personal training that goes through vocational training}

By reconstructing their memories, former students use the terms "CFP" or "school" or "college" to indicate the training context. By analyzing their language, we can say that they were at school (if with "school" we mean a safe place, intentionally aimed at training and education), but without the sensation of being at school (if with "school" we indicate a distant place from life, in which the training is perceived as an effort end in itself). Beyond the expression used to name the context, all participants have experienced the vocational and personal training as intimately connected. They also have lived the work experience as a context rich of learning: the work has become for them an important learning object, but they haven't learn a job just for work, that is, to enter the world of work, they have learnt a job to grow up as individuals through the job.

a) Learning a work from and through the work: the learning objects

Although the learning of a profession takes place on the workplace, many of the interviewees state that they had already acquired in VET Centers the skills and the basic notions to start to work. An example is reported in the excerpt below:

The basic notions that I have received have been very important; once the school was over, I could already use the machineries; I wasn't an expert in turning or milling, but I had the idea of how those machineries worked and how I had to use them. That was a suitable basis to start [...] and, at that time, the Salesians made me see the mechanical engineering in a really nice way [...]. Of course, the CFP gave me the basis, then on the workplace I've actually learnt the trade (IntFoss7).

The training experience has provided to participants the basis to move within a specific workplace, understanding the processes, its functioning and the general dynamics. The learning of real vocational knowledge takes place later, in contact with the problems and the challenges of concrete working 
situations. But almost all the former students interviewed declare that the VET Center hasn't only taught them a job, but it has enriched them as individuals: in CFP personal education and vocational training were intimately intertwined. Let's see an example:

In addition to professional growth, the CFP has allowed us to grow at human and personal level. We grew up being together day after day, facing problems. My teachers for me were like parents: they haven't taught me only what I know about work, but they have also contributed to my individual growth. Sincerity and honesty were very important in their interactions with us. They always had a direct attitude, facing all the problems that could arise in this area, without neglecting the human dimension; this is what helps to grow up (IntCt20).

Personal and vocational training are not different areas; they are both part of the same learning process. The personal knowledge is inextricably linked to professional one and, through the work, it is possible to learn also what helps to grow as person. This can be confirmed in the various testimonies, where interviewees talk about the values of honesty, sincerity, transparency and respect that in CFP were translated into relational and working behaviours (Rose, 2004). Many participants claim to have perceived the learning experience in CFP as intimately connected to the practice. Here's an example:

From the point of view of scientific training I've learnt several things; but manual skills, PLC programming, assembly, construction of electrical circuits, etc. are things that are non taught at universities, at least not in Italian ones; even at ITIS, where I went for the Diploma, they were issues treated but not applied to the latest technologies, while here at CFP these technologies were already available. I was more informed about these subjects when I was at CFP rather than when I was at Polytechnic; a friend of mine who graduated with me is now learning PLC programming, he wasn't able to do that because he had studied at high school and then in Polytechnic, while I already did this ten years ago (IntFoss4).

L. (IntFoss4), graduated in engineering, says that he deepened his technological knowledge at CFP, in a way that not even the University has made possible. Many participants also claim that at the VET Center they have learned to learn, that is, they have received significant methodological information:

The most vivid memory I have is when we started to compose in typography, the mistakes I made at that time; now the typography is obsolete, the technology has changed. At the CFP I definitely learnt a job, although today everything has changed [...]. The CFP has given me the basis to start to work; I knew nothing of this job and there I have received the practical basis but also a good theoretical preparation. I have often confronted myself with some people who have learnt-by-doing, without having attended specific professional training courses, and I noticed that they did not know many technical aspects related to the operation of machineries, things that I learnt at the VET Centre [...] ; I learned a job but above all a methodology (IntCt26).

At the CFP you receive an overview of a job [...] There, I haven't learnt only the subject, but also a method; I have learnt to accept the challenges and to overcome them. [...] I've started with the file, but I have always observed what the teachers did and then I succeeded in doing it again (IntCt7). 
The comparison that P. (IntCt26) makes between his experience and that of those who learnt only on the job, is indicative of the fact that what is important is not learning the proper functioning of the procedures, but the conscious development of a working method. Other former students claimed to have learnt at the CFP a method enabling them to face the problems, not only working ones, and many of them declared to have developed specific professional skills together with personal, social and interpersonal skills, which can be called transversal competences and that enriched them:

The Salesians have taught me a job, but at the CFP, I have learnt to live, to be patient, to listen to others, to be in society [...]. Thanks to their teaching, I see that I have a treasure in my hands, in addition to a profession; today, with what I have learnt [...] I'm able to enter in the young minds of my students (IntCt14).

At the CFP many participants have found out that the sharing of working experience, but also of other moments, such as games and sports, creates bonds and solidarity leading to relate to others in a positive way, and increases mutual understanding. In short, our former students have learnt in CFP how to become an adult, that is, to be able to take responsibility and to contribute in making a society of greater justice and solidarity. Furthermore, many participants say that in the CFP have succeeded in developing a positive attitude towards the work. Let's see an example in the following excerpt:

I remember the period of the CFP as one of the best times of my life, because at that age you start to socialize with classmates and with the environment around you. I remember there was the joy and the satisfaction of doing a good job and we worked with commitment and discipline. There were moments of leisure, we also did trips or picnics; there was the time to work but the time to play too and I've always liked this mix [...]. In the three years of CFP, I learnt how to work with machines but I have also realized how to do various jobs well, because an environment like that encouraged you to give your best. Before we did works with the file, then with the machinery, but doing a job well was, and is, a pride, a moral gratification. If I do good works, the people benefit from my service and speak well of me. You should always do your best, to make your work better [...]. Someone thinks that ours is a job where you get your hands dirty, but you should not worry about this; it is important to always do a good job, at any level; people need to know that there is someone who can do that job well becoming a point of reference (IntCt16).

The participants in the research say that in VET Centers they have learnt to work with pleasure and to work well. As S. (IntCt16) reminds us, the satisfaction of a job well done is not external to work as the saying goes "first duty, then pleasure", but it's intrinsic to the work and acquires ethical consistency becoming an opportunity for building the common good. It is this that increases the will to work, gives a different quality to the work and induces to find solutions to problems that may occur. It's like saying that at the CFP our former students have learnt that the dignity of every job comes first of all from the attitude with which a work is approached. In every job it is important to put something of yourself and this is reflected on the "work style" and on the relationships that are created through work. This is an aspect that many participants said they had learned directly from their teachers.

b) Learning from and through the work: the training strategies 
The previous discourse on learning objects cannot be separated from that one of training strategies. We can say that, in the educational experience lived by our participants, the work became a real educational resource. It is through the practical work carried out in the workshops of the CFP (designing, making artifacts, assembling, etc.), that our participants have been able to approach effectively also a general learning (learning by doing). Moreover, the concepts that are learnt by doing are different than other pure academic learning. Through the work, our students have learnt more; they often have been able to even recover the knowledge of theoretical disciplines, by merging it to the practice and to the workshop. In the following passage, M. (IntFoss3), an artisan of Piedmont of 38 years, remembers how the manual work has improved his ability to fully understand things:

I deal with both production and administration of the company. I do a little of everything, from working with the machine tools to the budget and the contacts with the customers. To do this you have to know also how to work manually. [...] I can say that, since I have workshop basis it's easier for me to submit an estimate or understanding things. The CFP made me know the milling, the grinding; we were able to do a bit of everything: lathe, milling machine, electronics, pneumatics; we knew different aspects of the work. I am grateful to CFP because there I learnt to use manual machine tools. Now only numerical control machines are used, but some pieces need to be smoothed and on a numerical control lathe the bevel doesn't exist, only the piece finished exists; there are parts that need a further process, which is handmade. I remember that at CFP teachers made us filing. The filing is annoying but it's the basis, it's what allows you to learn how to use the tool. It was good to see the teachers who dedicated themselves to the filing too. Now the piece exits finished from the machine, but for some work you need to be able to use the file. If you're good in that, everything is easier: you load the piece into the lathe chuck for the machining; if it will not work, you must use the sand paper (IntFoss3).

M. stresses that through manual work he has been able to develop professional skills such as calculating and graphic skills, a correct knowledge of materials, but also attitudes like the attention to detail and the ability to deal with problems that may arise. Many former students tell us that they have experienced what might be called a "manual" approach to knowledge (Bertagna, 2011).

In the stories is also emphasized how the workshop is a learning environment. Here it was possible to have a concrete job experience in a protected setting:

The workshop was at the basis of all Salesian organisation [...] it was well structured and, when we didn't understand something, we were given an additional explanation [...]. For example, in my area, the electromechanics, we studied before the civil and industrial installations - the functioning, the wiring diagram etc. and then we realized the mounting on panels created by the teachers; then maybe you could find the same electric panel in a factory and you knew how to work on it. The same thing happened with the adjustment, they taught us to weld, to use the drill press and to file; the teacher explained us how the piece of iron had to be drilled and tapped and after that he made us practise; if we did it wrong, he corrected us, if he had to scold, he scolded us, but always for a good cause (IntCt17). 
Of those years the person that impressed me most is M. for his training and seriousness; he was my professional art teacher and I still remember his desire to do, his way of relating to us and his preparation. D. stayed among us and I've always liked it: [...] he was always well-prepared and with a great will to work; he expected total commitment from us and he made us work hard; he was very professional, he spent hours preparing the lesson; [...] he succeeded in transmitting to his students the desire to learn and to build complicated things. Actually we've never done easy things with him; in six hours we had to build a piece and he tried to help us doing it. There were also eleven, twelve machines, and each machine required a different work; they needed to be equipped and this took a long time; in the six hours we had to finish our work and disassemble the equipment doing a good job (IntBra4).

The workshop is the flagship of the Salesian VET Centers (CFP), where "the most important things" can happen. G. (IntBra4), who is now a trainer, describes the passion for the work of his trainers and the care taken in the preparation of the workshop activities. The workshop was, and still is, the place where students can measure themselves with a real work and can develop their desire of "learning to build complicated things". For this reason the Salesians have always been committed to the continuous updating of the workshop and the equipment. Often our former students have been able to work on the same machines that subsequently have found in companies. In the following extract, F. (IntFoss5), who attended the CFP in the 60s, well describes how this education was centered on the workshop:

I've always had a gift for the mechanical engineering: disassembling the motorbike to my dad, at the age of twelve, was a normal thing for me. Being in this school, where there were at least five hours of workshop per day for me was the best. We experienced the building of something, we had the satisfaction of doing something important. All of this was valued at that time; we did many things such as dismantling the motors, rebore of agricultural tractors, works on bodywork, etc. These things gave satisfaction and for a boy who was 14 years old it was like touching the sky with a finger. For someone like me who has always been fond of mechanical engineering this was very important. It wasn't a sacrifice studying technology or working with a lathe [...]. The school gave me the basis to work with a lathe in a practical way and to understand, in addition to the theory, what are the working conditions to assess if the theory that I was applying was correct (IntFoss5).

F. finds continuity between his family experience, that put him in contact with the work experience (help to his dad, summer job etc.), and the experience at the CFP. The pleasure of doing things and the satisfaction felt, made the effort of attending each day the CFP bearable. The interviews reveal a further aspect of this workshop approach, which consists in the enhancement of authentic tasks †े. Let's see an example to understand what it is:

The first year they made you create an object with the file and the lathe. It gave satisfaction! Everyone had to do a piece. Every day we had lathe, grinding, welding. If you wanted, you could make an iron sphere; I made it, everybody made it, we burnished it, grinded it and then we put it on the desk as a paperweight (IntFo1). 
The enhancement of authentic tasks consisted in giving tasks as in real contexts. In this sense, the workshop was an ideal authentic setting, because very similar to a workplace. In all the cases analyzed, the workshop teaching appears like a teaching, which leads to reflect on what you do. The reflection accompanies the whole working process: it anticipates the work in order to plan what to do, it develops during the work, in searching for information to find a solution to the problems that may arise, and after the action as a retrospective look on the work.

Our participants had the chance to experience at the CFP also a collaborative learning, as described in the following example:

At the CFP I learnt a job I wasn't able to do, but I also learnt to stay with the classmates, to share and to collaborate with them at work. When I attended a technical school, I had the advantage that I had already learnt the meaning of that profession and I was able to collaborate with the others (IntCt7).

The testimonies show that the CFP allows live a healthy relational climate, based on collaboration. In the experience of some research participants can be seen how the collaboration between students has been very important for the recovery and the enhancement of learning. Good relations in an educational context are not only rewarding for the students, but they also help to learn better.

Many of our former students describe that the contact with the world of work didn't occur only in Salesian workshops, but also in real work context and they stress how the early contact with the labour market has been essential for them to have the opportunity to combine learning and work experience. In conclusion, we point out that it's through the contact with the work, that our former students have found in the Salesian CFP an education, which has fostered their creativity, their ability to learn, to design and to interact with other people.

\section{A training that mobilises energies}

The interviewees have given us stories that show, how the learning experience have made them go far beyond difficulties. Here we report some testimonies, which help us to see how the energies of the students have often been addressed to transform negative experiences into learning opportunities. Very often the educational success described in the stories collected has been built on the ruins of a previous school failure. But from the testimonies comes to light that school failure doesn't necessarily imply training failure. The research participants said they had found in the CFP people who have helped them to discover their unexpressed potential. In their stories the success has been important, but equally important has been the failure: for many of them the contact with adults available to help them has been essential to turn the failure into a learning opportunity, the mistake into an occasion to learn. The experience at the CFP has marked a turning point in the biography of interviewees and made them "desire to learn more and always": 
At the CFP I've learnt to compare myself to others and to increase my will to go on. [...]; I've realised that if you don't keep up, you're left behind. Today I am where I am thanks to this desire to learn more that I developed at the CFP. This experience helped me to socialize with my classmates and to give meaning to my personal and working future. It also taught me that without hard work there is no success. (IntCt21).

At the CFP I learnt to never back down thanks to my teachers, because they haven't only taught me how to use a screwdriver or how a power cable must be passed, but they also taught me to always take a challenge. Before starting to work on my own, I did everything - the electrician, the painter, etc. - because the Salesians taught me to never back down and not to stop in front of the first obstacle. They taught me to be determined and to always complete a job (IntCt17).

The one described in the many examples is a free training which releases potentialities, mobilises energy and helps to overcome the difficulties and the obstacles.

\section{A training that orients in life}

The participants in the research declared that their experience at the VET Center has gradually oriented them not only in the choice of an educational or a career path, it has also oriented them to the living style. First of all, the CFP has been for the students like a "gym" to train to work, as described in the example:

I remember there was a lot of dialogue with the teachers; they oriented us on anything related to work: career prospects, the behavior to adopt and the best way to relate to people. The teachers who have followed me taught me how to work, how to behave in the workplace, how to pay attention to the machines. The center was a kind of gym for work; there we gained experience in order to be prepared once outside. I have to say that their teaching has been helpful; in the company it hasn't been hard to acclimate myself; I started as a worker and now I am production manager. Attending the course helped me to understand what I wanted and what I would have done once finished the school. Today it's difficult to orient (IntCt13).

As emphasized by N. (IntCt13), the existing conditions make the orientation to the world of work a lot harder than before. Through the experience gained at the CFP, you could get an idea about the world of work, but also give space to your own desires and dreams, to focus on your potential, inclinations and aptitudes or you could get the opportunity to identify further training paths. Here's another example:

I studied for three years at the VET Center of Fossano, electric sector, after which I moved to ITIS, in order to get a high school diploma, and then, I wanted to try the college experience and I studied electronic engineering and I ended [...] with excellent marks [...]. At the CFP it has been really important, especially for me, to experience the manual work because it's what has distinguished me from the other students coming from high school. At the CFP the teaching was based on technical aspects, we studied little Maths and Italian, but the fact that I have been prepared in programming has been essential for me later, when I went to ITIS; maybe I wasn't so good in other subjects but I compensated with my practical preparation. At fourteen, 
one is not sure about what he wants to do; once finished my experience at the CFP, I had a better idea of what my path could be. I comprehended what were my skills and how I could have used them. To go to ITIS I had to prepare and to pass an exam and this made me realize that I had the potential as student and that I could do it. There are things required by companies that the CFP gives you, but that, paradoxically, high level education doesn't give you. (IntFoss4).

It's like the CFP had given the opportunity to test themselves and make them aware of their potential. L. (InFoss4), who is today an engineer, has lived the training at the CFP as a unique and efficient experience, capable of developing work skills and to orient students more generally in life. Each of them, in fact, has experienced an orientation not only to identify his professional goals, but also, we can say, to choose himself, to develop his individuality. After all, it's not only about deciding what job to do, but also what person to be, through the work which you decide to do.

\section{Job placement assistance}

In this section, we will analyze job placement and support as specific types of intervention in VET Centers. The CFP accompanies the students into the labor market and keeps on offering consultancy support to sustain alumni's effort for securing successful occupational role. We can say that our former students have been lucky to meet the teachers of our center who have been able to take their educational mission and to facilitate the entry of their students into the world of work in order to give them the opportunity to take active responsibility in society. As reflected in many testimonies, being trained by the Salesians CFP is taken as the good credentials during a job interview. Very often, when there was more job offer, the companies looked for someone to hire contacting directly the CFP and asking for the best students:

The CFP is very popular; for example, in these days I did some interviews in various engineering businesses: they already knew VET Centers and they are pleased that one had practical experience in a CFP (IntFoss4).

I arrived at a company, at that time (late '60s), sponsored by the Salesian school of Fossano; at that time [...], it was normal that former students were hired by the company; [...] the Salesian school was well known and appreciated also by Fiat [...]. I've started to work the week after finishing school; that morning sixteen former students have been hired [...]; I was good at school and this helped me a lot in the interview that at the time we did with Mr. B. in person (IntFoss5).

So Salesian VET Centers can provide a better job support ensuring high quality vocational education. This can be seen the story of L. (IntFoss5), who finished his training in 1966, and in the case of F. (IntFoss4), who finished a few years ago. In many cases, the Salesians or the lay teachers can intervene directly to help people in finding work by word of mouth. Several former students have found a job in the same companies where they had previously done the internship provided by their learning path. In addition to support in finding job, the research participants were given help in setting up a business. 
Testimonies show how the learning experience at CFP has succeeded in educating at the assumption of responsibility and at the development of initiatives and how vocational training has been successful in instilling the courage of taking risk and the self-confidence which allows you to get high goals. Often the CFP itself has been a source of new business ideas, as in the case reported by A. (IntCt29), in the following passage:

At the time, Don A. enlightened me; he was the responsible for the electromechanical department; everyone considered him an unfriendly teacher, but with me he has always been very helpful, so much that, after realizing how much I was interested in electrical engineering, he taught me how to build a transformer. I had no difficulty in placing this model on the market, because it was a really good product; the other transformers on the market did not have the same duration. During the last years of his life I visited him to thank him for what he had done for me; I told him that the transformer, thanks to him, was known and sold all over the world, and he said, that all this was happened thanks to the Lord. Today I can state that "thanks to the Lord," as Don R. said, we keep on building electrical transformers, always in the way he taught me (IntCt29).

The teachers at the CFP have helped former students in the development of business ideas, in what we would now call start-up. Sometimes the CFP itself becomes the workplace of former students. We can see through the testimonies that very often, especially in Piedmont and Sicily, it is implemented the strategy of selecting the trainers among former students:

I'm a freelancer, I have many clients, I do welding, consulting, mechanical design; I also teach welding and workshop at this center, especially in the evening classes for adults, unemployed and laid off; this year I teach welding and workshop in three courses for apprentices (IntBra5).

I've been working in this CFP for about thirty years; I started as a simple trainer, then, over the years, I've become the coordinator of the graphic sector. I teach offset printing; [...] I am also a former student; after completing the course, I've been working in a company dealing with the printing for four years, then I was contacted by the coordinator of the sector of that time, Mr. C., and I had the opportunity to begin to work as trainer, after getting an expert technician diploma (IntCt3).

Former students are very good teachers because they already have lived the training in a CFP but at the same time they have also gained experience in their specific professional field. In some cases, the CFP offered support to people who were living moments of difficulty because the responsibility of trainers doesn't finish with the end of initial training. The cooperation network between former students, maintained in VET Centers, could become an important resource for creating employment. This is testified by participants who say that they search for collaborators among former students or they have been hired by former students or they have started a business with their former schoolmates of CFP. The fact that they shared an intense training experience leads them to share a style and a sensibility that may help in professional collaborations. The current situation of economic regression, marked by growing youth unemployment and job insecurity, makes all this more difficult but also more necessary to enable 
young people to achieve professional growth. Today, the Salesian VET Centers seem to be one of the few realities, which provide resources to help young people in finding their own way.

\section{Portraits of trainers}

How are the trainers in the eyes of their students? In the following paragraphs we will try to identify the various training styles that research participants have attributed to their trainers.

\section{Significant and helpful adults}

Teachers, in the etymological sense, are those who "leave a mark", provide keys for reading and interpreting reality. The trainers in the stories of former students appear to be faces imprinted in their memory, credible adults who gave their best in teaching. Below are some examples of descriptions:

I remember the relationship with teachers [...] maybe it was because we spent long hours together, but the teachers were also our friends. This certainly helped to move forward. With the teachers we talked about everything, not just about school. Sometimes it happened that I had something on my mind so I went to speak with the teacher and he told me something more about what I needed. The relationship with the teachers has been a very important incitement. I remember everyone of them for their niceness or friendship that we created: there was the teacher who could play good football very well, the one with whom we won the table tennis tournament. Talking about workshop I remember G .: I liked how he worked on the lathe; I envied him because he was really good at it, I liked watching him at work; I tried as much as possible to steal with my eyes his working method; I remember an evening when he was working some pieces of wood on a lathe; I asked him if I could stay because I didn't know how making a bowl on the lathe, and I was permitted to remain; it has been a very nice thing for me (IntFoss7).

Mr. V. explained calmly and made us apply the things he had said; we, the students of second and third year, wanted to learn, in the afternoon we stayed at the centre; he made us build some small aluminum molds, making us work on the milling machine; he assisted us calmly also because in the afternoon we were only three or four, explaining us some tricks. That kind of education has prepared us very well (IntCt6).

Teachers, especially those of workshop, are impressed in the memory of students for their expertise and availability. In memories, they often appear associated with names and concrete images. G. (IntFoss7), recalling the teacher of the workshop, said that he felt real admiration for his technical competence. In the story of V. (IntCt6) the teacher seems to be the master craftsman of the past, from whom it was possible to learn the tricks and the secrets of the profession. Teachers shared with the students the whole day, (lessons, leisure time and canteen), building meaningful relationships, facilitating the dialogue:

The memories I have of the CFP are related to the teachers I've had, if you didn't understand, they stayed for extra lessons. The relationship between students and teachers was familiar. I remember that during break time we were always together, although there was respect. If you did not understand any topic, they helped 
you; there was a lot of dialogue, and that has been useful for us into the working world. [...] The eighty percent of us has continued in our field, turning and milling, because the teachers believed in us and they put so much enthusiasm in their teaching that at last we believed in ourselves too [...]. I remember the teachers devoting much time to us; we spent many hours in the workshop, and then when we entered into a real workshop, we were prepared. The teachers believed in what they were doing. [...] We spent all the time, from morning to evening with teachers; sometimes we made a joke. Even the more rowdy boys, who got up to all sorts of things, remember those years as the best of their lives. Everything was nice, also when the teachers scolded us; the trainers were mentors to us, they talked about what there was outside the school, and shared with us even the canteen (IntFoss3).

M. (IntFoss3), who attended the CFP living in the boarding school, remembers very well the availability of teachers, their contagious enthusiasm and passion ("they believed in us and they put so much enthusiasm that at last we believed in ourselves too"). Our students convey that often their teachers became a model not only for a professional growth but also for an individual growth; they stress all the features of trainers: their availability, reliability, friendliness, attention to individuals.

\section{Passionate witnesses to their work}

In the eyes of research participants, one of the features characterizing the style of their trainers is that of being witnesses. First of all, teachers are perceived as witnesses in the sense of people who witness values, embodying them:

The Salesians to me have always been an example to follow; in addition to Mr. C., we had Mr. O., an expert manual composer; I remember him talking about Don Bosco; [...] he didn't talk about Don Bosco as an unreachable figure, but as someone who could inspire us to do the same. Not calling them teachers, put you in a position to make you feel like a son for them. You didn't learn how being parent only from your family, but also from these people who were like parents for us, because every day they looked after fifty boys as they were their children; this has helped me for my role as a parent (IntCt3).

The teachers gave us something that went beyond the teaching, they were as friends for us and transmitted something that surpasses the knowledge of the profession: they taught us life lessons and respect for other people. The school has helped us to grow up (IntCt19).

The story of C. (IntCt3) doesn't only show that his teachers represented for him examples of values embodied, but also that, through narration, they put them in contact with models of life with which to identify and to which they can inspire. A. (IntCt19) recalls how his teachers, with their actions and not just with words, taught something that went beyond the professional knowledge. In many stories, not surprisingly especially in those of former students who have become trainers, teachers appear as those who "pass the baton": 
We had teachers who indicated us the way. I remember the teacher of the first year that gave me satisfaction when I was doing something good. Teachers prepared us to work giving the example: they showed us how to work with a machinery; of course there were those who paid attention and those who played with the classmate; however, our teachers were always willing to help those in need [...]. The student observes the teacher and his work: if the teaching is good, the work of the student will be good. My teachers were expert and I try to transmit what they have taught me. They helped me even temperamentally, because here the teachers are also educators. Currently, I can understand if a student is performing a job correctly, even only by the noise of the machines. When I say to a student, that he's doing wrong, he's amazed that I could understand it even if I'm far from him. Often my teachers did the same with me: after a lesson was explained and repeated, they didn't help us in order to see if we were able to work independently. I remember G. who was very meticulous, also about how to behave in the workplace. He applied a method based on a principle that I have always loved: the workshop is like an orchestra, everyone should have its place and should know what to do; if everyone works in its own way, you do not create harmony. We watch the students as well as our teachers watched us [...]. I remember very well how was being a student, so I try to set an example telling my personal experiences in the workshop and in the classroom. If we don't leave a strong impression on the students they will forget our teachings. It is something that is transmitted: if I teach a low quality education, the students receive it only partially and they're not able to improve their process (IntCt16).

I teach young people also through my life experience, saying that through education we give the basis to learn a job; we're like the parents who teach their children to walk, who must then walk alone [...]. With enthusiasm, I keep on working here [...]. The CFP needs models of life who teach by example that you must not squander, you must be punctual and punctilious; all these things, day after day, encourage the person to improve, to do things as right as possible leading to inner satisfaction. This is what I have experimented on myself and then I have tried to transfer to my students. At first it seems that these things are not assimilated, but after a few years these seeds germinate. My trainers have done the same with me. My teacher was Prof. S., who was very meticulous and his being so accurate in his things, day after day, in some way influenced me. If at the CFP I found unwilling teachers, with little interest, I do not know if I would have been able to do what I have done in all these years (IntCt8).

Our trainers put us at ease, they worked next to us; the teacher was the first who started to work, so for us it was automatic following his example. Today I do the same, so the students see me as a worker; I've never worn a suit at school; If you teach practice, you have to show that you're working, you have to teach how working; students do not see me as a trainer, but as a worker; I'm their workshop manager, not their teacher (IntCt14).

The stories of S. (IntCt16) and M (IntCt8) describe not only the teaching strategy of "showing how to do it", implemented by the teachers especially in the workshop, but also their way of communicating through their way of being, rather than only through words. So the teachers become an example to follow for growth and changing. They are also example of possibility, the possibility that a certain path is possible: it 
is possible also becoming teachers through commitment. The trainers of the stories are former students and use their past experience at school as resources in teaching ("They did the same with me", "I try to transmit what they have taught me", "It is something that is transmitted"). E. (IntCt14) explains how his teachers, working next to their students, embody passion for the job, making acceptable the effort that hard work necessarily involves. In the history of the former students who have become trainers we have the representation of the task of "restitution": what has been received is returned to new generations.

\section{Teachers able to combine strictness and cordiality, professional expertise and human relations}

There is a recurring aspect in various testimonies: the ability of trainers to naturally combine strictness and cordiality, professional expertise and human relations. It's their skill of being both friendly and strict that is particularly impressed on the memory of former students:

The Salesians have a specific style: they are very strict in the classroom, but friendly like brothers, in the courtyard; they played with us, this was their method. Any problem we had, they were ready to listen to us, and to give us some good advice [...]. Among the Salesians there were very nice people, even if I didn't get on well with everyone. Many of my teachers were Salesian: they have always treated us with special care (IntCt10).

I remember the seriousness of the CFP: in the morning you had to come to school and you could not go around the city [...] even if you had a headache, one of the parents had to call the director and justify the absence. The teachers were very serious and prepared. They were more fathers than teachers, they tried to orient us. With them, especially with some, there was a special relationship [...]. They used the same method than Don Bosco: using good manners, but also strength, when it's required. When we did something wrong teachers rebuked us, never offending us, and they explained us the mistakes. I have always had in my heart Prof. R., who was a man of experience; he was very special for me because he made me understand the profession and the reality (IntCt17).

The Salesians seem to have a unique style inspired by Don Bosco, as can be seen in story of P. (IntCt10) e G. (IntCt17): being very demanding with students in the classroom and in the workshop, and being their friends, as elder brothers, in the courtyard and leisure time. Our former students say that teachers expressed strictness only through the eyes, but this was actually also a way of expressing affection. Seriousness of teachers was proportionate to their expertise and, in the memory of participants, combines also with relational skills:

Prof. A. was a really good teacher, he could interact with young people and teach efficiently. He explained first, then he made us do what he had explained, monitoring if we were doing a good job. [...]; Prof. A. was always well-prepared about what he had to teach and he taught creating a good relation with us (IntCt27). Teachers were good and there was a relation with them, like a friendship; I had a good relation with my Prof. C. who was my point of contact for the printing machine; then there were Prof. A., Prof. O. and Prof. C. I 
remember them as smiley but at the same time meticulous teachers; they are impressed in my mind for their ability of combining sweet and bitter [...]; they taught us a trade but also useful values for our life (IntCt24).

I have a beautiful memory of some teachers, because they were good at teaching, they could laugh and joke, but also work. Certainly, the most important aspect for me has been finding a fair and just figure in my teachers who loved their job and being in contact with young people [...]. There were many problems because it wasn't easy to create a serene atmosphere in the classroom. In my opinion, being able to create this atmosphere is the main virtue of a teacher (IntFoss8).

S. (IntCt27), recalls a particularly skilled teacher ("was a really good teacher") who accurately prepared his lessons and was able to teach creating a significant relationship with students. This aspect is highlighted also by D. (IntCt24) saying that his teachers could combine "sweet and bitter". W. (IntFoss8) stresses their professional expertise but also their ability of joking with students in order to create a serene atmosphere; they "loved their job and being in contact with young people". Other former students too remember the ability to build up a relationship of their teachers:

We had really good teachers; I have a good memory of them. At human level, they created a personal relationship: they asked us about our families, if there were problems at home, if we were doing well at school. At the time the Director was don B., a memorable figure. He taught religion but he was also Director and when he scolded us, when needed, he talked to our parents, he remembered of everything and everyone, and was concerned about us. I have impressed in my memory his, and that of W., ability to remember about everything about the students, the names, where we came from [...]. We were like children for them: if we didn't go to school they phoned home (few schools do it). My classmates had serious problems in their families, they were mistreated; teachers tried to help them, as far as they could. Practically, the Salesians raised me, because those are crucial years when you can go to the bad, they are years of choices but at the CFP we were monitored and helped. For example, if someone at school used drugs, there were real consequences: the police was called, you were suspended and sometimes even expelled. They did this to protect us, because those are the years in which young people are exposed; then growing up you realize that is not right doing such things, but at that time we were at risk (IntBra5).

We felt protected and guided to the right path. The trainers cared about us. There was euphoria, the center was always full of Salesian teachers and boys [...]. I remember don B. [...] an extraordinary man [...], full of goodness; he spoke little, but he was ironic and funny, he built small things for the boys, such as a hot air balloon; they were attracting things [...]. Our teachers made us understand what they explained also because they involved us in various initiatives: a football match, table tennis or the theatre that was organised at school. Students considered their trainers as fathers; teachers taught also through recreational activities, so we went to school happier (IntCt6).

M. (IntBra5) met teachers who assumed responsibility to take care of students, building a personal relationship and showing interest for everyone of them, creating educational alliances with their parents and orienting them towards good choices. V. (IntCt6) too remembers the affection and protection received 
by his teachers. They were friendly, but also strict in the respect of rules. The teachers that our former students remember were convinced that the respect of rules and the sense of duty represented a "way used by a worker to express respect for others. In this way, his work can contribute to the common task of producing a value that is not just economic, but also social, relationships-wise and collective" (Pizzul, 2012, p. 37).

\section{Talent discoverers}

The research participants state that during their training they managed to give their best and to grow up thank to their trainers who have succeeded in finding in them the hidden potential:

I remember that Prof. M., at the time, said he would see me as a good engineer; he was a prophet. He hasn't said this explicitly to me, he said to my parents, during a class meeting where the situation of the student is focused; then, when my parents have told me, I felt flattered; certainly it was good news that someone had these ideas about me. I didn't have much self-esteem, so I needed someone to believe in me (IntFoss4).

These teachers are able to recognize the unexpressed skills of their students, even those hidden, and to discover what they could become, creating the conditions to use their energy that would otherwise be wasted. They can identify promising things in students and develop their self-confidence exalting their skills.

\section{Conclusion}

The importance of vocational training comes not only from its content and the competence of teachers, but also from the human values transmitted and the influence that the school had on the lives of students. The interviewees stress how the CFP has been for former students. The assumption behind the question is that the practical approach utilized in the CFP courses made possible the enhancement of talents, for which school education judged to be inadequate. Analysing the current life of former students we can deduce that VET has contributed to their professional and personal success. Reassembling like a mosaic various aspects of their life, our former students discover how the human and professional training received at CFP have helped them to have success. An important clue to successful life is the chance to experience that there is a deep connection between the taste with which a job is done and the chance of being happy. Many former students have been able to find this link already at CFP. The words of Primo Levi in La chiave a stella ("The Monkey's wrench") comes to mind: “...loving one's job (which is unfortunately the privilege of few) constitutes the best concrete approximation to happiness on earth" (Levi, 1978, p. 81). From the testimonies it doesn't emerge only the satisfaction of doing a job, but the taste of doing a job for others. Many former students are aware of the importance of putting into practice what they have experienced in the CFP and to hand over to others what they have received. Even this can 
be seen as a sign of successful training. Several former students have become trainers and try to teach with the same passion of their teachers of the past. But also the family and the company are contexts in which it's possible to return what it has been received, investing in human relations. Research participants consider the experience of the CFP as crucial in their growth, which has often represented a real turning point or the opening to new possibilities. They see their personal and professional growth as directly attributable to the CFP, rather than to other learning experiences. It was a precious time to learn a trade, but also the spirit to do it. Often the chance to assess themselves with concrete tasks has allowed them to develop a deeper understanding of things in a much more effective way than some academic learning. For many former students the CFP represents the place in which a change happened, the place of a turning point, but especially, the place, which made them feel part of a community. Being with those who shared the same educational experience creates a bound of common commitment and it is this that establishes the sense of being a community.

Although not generalizable, the results of this research allow make a positive judgment on a successful training path based on the enhancement of the work. It's a "Salesian" VET, with specific features, which worked and could work also in other contexts. We started with the idea of studying cases of "educational success", but the educational success is not just "getting a degree", but also developing and cultivating a talent, particularly for those who come from a socio-economic and cultural disadvantaged background. The stories of former students show us that they have lived a training work experience, creating bonds and relationships with others, discovering work as a special occasion. The testimonies talk about something bigger than personal training success that is made up of values and interpersonal relations. Therefore, we would like to conclude that the element that makes the difference in a training path is not so much the nature of the training itself but the quality of the training course. For many students the training has meant hope and orientation. In Salesian VET Centers the research participants have discovered the work as training and educational resource. It should be recognized the added value of the CFP proposals for personal education and vocational training, abandoning the underestimating prejudice that CFP are only for those who have been abandoned by the education system, those considered as "waste".

The source of this research is the voice of the students, rather than that of teachers. Many former students have vivid memories of their trainers, they left their mark because they have been able to encourage and trust in them; often teachers have remained a guide for students even in adult life. Trainers are generally aware that the success or failure of their actions cannot be measured only in the time of contact with the students: the future will tell if the training path has triggered the awareness to which the trainer aims during his training activity. Our research has shown that former students have effectively acknowledged that the teachers met at CFP have become very important in their lives, because they have 
been able to involve them into a valuable collective enterprise that has been turned into the series of "stories of value" that former students have given us.

\section{References}

Atkinson, R. (1998). The Life Story Interview. Thousand Oaks, CA: Sage.

Bertagna, G. (2011). Lavoro e formazione dei giovani. Brescia: La Scuola.

Bruner, J. (1992). La ricerca del significato. Per una psicologia culturale. Torino: Bollati Boringhieri. [tit. or. Acts of Meaning, 1990].

Cavarero, A. (1997). Tu che mi guardi, tu che mi racconti. Filosofia della narrazione. Milano: Feltrinelli.

Clandinin, D.J. (2007). (Ed.). Handbook of narrative inquiry: Mapping a methodology. Thousand Oaks, CA: Sage.

Coles, R. (2004). (Ed.). Teaching Stories. An Anthology on the Power of Learning and Literature. New York: The Modern Library.

Dahlberg, K., Drew, N., \& Nystrom, M. (2002). Reflective lifeworld research. Lund, Sweden: Studenlitteratur.

Damiano, E. (2006). La Nuova Alleanza. Temi problemi prospettive della Nuova Ricerca Didattica. Brescia La Scuola.

Demetrio, D. (1996). Raccontarsi. L'autobiografia come cura di sé. Milano: Raffaello Cortina.

Dutto, M. G. (2013). Acqua alle funi. Per una ripartenza della scuola italiana. Milano: Vita e pensiero.

Edmunson, M. (2002). Teacher. The one who made the difference. New York: Vintage Books.

Glaser, B. G., \& Strauss A. L. (1967). The Discovery of Grounded Theory: Strategies for Qualitative Research. Chicago-New York: Aldine de Gruyter.

Kozol, J. (2001). Ordinary Ressurrections. Children in years of hope. New York: Perennial.

Lackey, J., \& Sosa, E. (2006). (Eds.). The Epistemology of Testimony. Oxford: Clarendon Press.

Levi, P. (1978). La chiave a stella. Torino: Einaudi.

Lombardi, M.M. (2007). Authentic Learning for the 21st Century: An Overview. In Educause Learning Initiative. Available at http://net.educause.edu/ir/library/pdf/ELI3009.pdf (Retrieved on 04/03/2015).

Mortari, L. (2003). Apprendere dall'esperienza. Il pensare riflessivo nella formazione. Roma: Carocci.

Mortari, L. (2007). Cultura della ricerca e pedagogia. Roma: Carocci.

Mortari, L. (2010). A cura di, Dire la pratica. La cultura del fare scuola. Milano: Bruno Mondadori.

Pastore, S. (2012). Lavoro e apprendimento. Intersezioni didattiche. Milano: Guerini e Associati.

Pizzul, F. (2012). Lavoro. Milano: In dialogo.

Prellezo, J. M. (2010). Scuole Professionali Salesiane. Momenti della loro storia (1853 - 1953). Roma: Cnos-fap.

Ricoeur, P. (1989). Dal testo all'azione. Saggi di ermeneutica. Milano : Jaca Book. [tit. or.: Du texte à l'action. Essais d'herméneutique II, 1986].

Ricoeur, P. (1993). Sé come un altro. Milano: Jaca Book.

Rogers, C. R. (1997), La terapia centrata sul cliente. Firenze: La Nuova Italia.

Rose, M. (2004). The Mind at Work: Valuing the Intelligence of the American Worker. New York: Penguin Group. 
Tacconi, G. (2011). La didattica al lavoro. Analisi delle pratiche educative nell'Istruzione e formazione professionale. Milano: Franco Angeli.

Tacconi, G., \& Mejia Gomez, G. (2010). Raccontare la Formazione. Analisi delle pratiche nei Centri di Formazione Professionale dell'Associazione Ciofs/fp-Puglia. Taranto: PrintMe.

Tacconi, G., \& Mejia Gomez, G. (2013). Success stories. Quando è la Formazione Professionale a fare la differenza. Roma: CNOS-FAP.

Van Manen, M. (1994). Pedagogy, Virtue, and Narrative Identity in teaching, Curriculum Inquiry, 24(2), 135-170.

\section{Footnotes}

*The Salesian Society is a Roman Catholic religious institution founded in the late nineteenth century by Saint John Bosco and engaged in education.

**In Italy CFP (Centro di Formazione Professionale - Vocational Training Center) are institutions accredited from the Regional Authorities where the initial VET programs take place. VET is the acronym of Vocational Education and Training. The VET system in Italy is very articulated. The National Government is responsible for technical and vocational schools (5 years after the students have completed the 8 years of the first cycle). The Regional Authorities are responsible for another kind of courses, the 'initial vocational education and training' ( 3 or 4 years after the first cycle), which are run by accredited institutions and provide specific vocational skills. These courses cover almost all sectors of economy, and lead to the award of a vocational qualification certificate recognized at National and European level. The qualification can be used to enter the labor market or to pass into Higher Technical Education and Training. Both channels (state-run technical and vocational schools, and regional VET centers) are linked to higher education, higher vocational training, and the labor market.

***In this regard, Max Van Manen states: «The present interest in story or narrative may be seen as the expression of an attitude that is critical of knowledge as technical rationality, as scientific formalism, and knowledge as information. Interest in narrativity may express the desire to return to meaningful experience as encountered in everyday life, not as a rejection of science, but rather as a method that can deal with concerns that normally fall outside of the reach of "normal" science (Van Manen, 1994, p.159). About this, see also Dahlberg, Drew, Nystrom, 2002.

For a complete presentation of the research it is made reference to Tacconi, Mejia Gomez, 2013.

****The research has been conducted by the two authors. The responsibility of this article is to be attributed to the writer. $\dagger$ The narrative form is the typical form of framing experience (and our memory of it) (Bruner, 1992, p. 65).

$\dagger \dagger$ The National Federation aimed at coordinating the Salesian VET Centers in Italy (see: www.cnos-fap.it).

¥ In Italy the title “don” is usually given to Roman Catholic priests (editor’s note).

$\dagger$ For a definition of authentic tasks and the resulting meaningful learning (Lombardi, 2007). 